OPEN ACCESS

Edited by:

Yosuke Aoki,

The University of Tokyo, Japan

Reviewed by:

Diana Roman

Carnegie Institution for Science (CIS),

United States

Alessandro Tibaldi,

Università degli Studi di Milano

Bicocca, Italy

*Correspondence:

Páll Einarsson

palli@hi.is

Specialty section:

This article was submitted to Volcanology,

a section of the journal

Frontiers in Earth Science

Received: 31 January 2018

Accepted: 13 April 2018

Published: 08 May 2018

Citation:

Einarsson P (2018) Short-Term Seismic Precursors to Icelandic

Eruptions 1973-2014.

Front. Earth Sci. 6:45. doi: 10.3389/feart.2018.00045

\section{Short-Term Seismic Precursors to Icelandic Eruptions 1973-2014}

\author{
Páll Einarsson* \\ Institute of Earth Sciences, University of Iceland, Reykjavik, Iceland
}

Networks of seismographs of high sensitivity have been in use in the vicinity of active volcanoes in Iceland since 1973. During this time, 21 confirmed eruptions have occurred and several intrusions where magma did not reach the surface. All these events have been accompanied by characteristic seismic activity. Long-term precursory activity is characterized by low-level, persistent seismicity (months-years), clustered around an inflating magma body. Whether or not a magma accumulation is accompanied by seismicity depends on the tectonic setting, interplate or intraplate, the depth of magma accumulation, the previous history and the state of stress. All eruptions during the time of observation had a detectable short-term seismic precursor marking the time of dike propagation toward the surface. The precursor times varied between $15 \mathrm{~min}$ and 13 days. In half of the cases the precursor time was $<2 \mathrm{~h}$. Three eruptions stand out for their unusually long duration of the immediate seismic precursory activity, Heimaey 1973 with 30 h, Gjálp 1996 with 34 h, and Bárðarbunga 2014 with 13 days. In the case of Heimaey the long time is most likely the consequence of the great depth of the magma source, $15-25 \mathrm{~km}$. The Gjálp eruption had a prelude that was unusual in many respects. The long propagation time may have resulted from a complicated triggering scenario involving more than one magma chamber. The Bárðarbunga eruption at Holuhraun issued from the distal end of a dike that took 13 days to propagate laterally for $48 \mathrm{~km}$ before it opened to the surface. Out of the 21 detected precursors 14 were noticed soon enough to lead to a public warning of the coming eruption. In four additional cases the precursory signal was noticed before the eruption was seen. In only three cases was the eruption seen or detected before the seismic precursor was verified. In general, eruptions are preceded by identifyable short-term seismic precursors that, under favorable conditions, may be used for pre-eruption warnings. In some cases, however, the time may be too short to be useful. The Hekla volcano stands out for its short precursory times.

Keywords: seismic precursors, eruption precursors, volcanoes in Iceland, pre-eruption warning, eruption forecasting, precursor time

\section{INTRODUCTION}

The interaction of the Iceland hotspot with the mid-Atlantic plate boundary leads to volcanism of unusually wide variety. The high rate of volcanism associated with the hotspot produces basaltic crust that is $15-40 \mathrm{~km}$ thick, 3-8 times thicker than normal oceanic crust (e.g., Bjarnason, 2008; Brandsdóttir and Menke, 2008). Extensional tectonism therefore occurs in an environment that is different from that of the oceanic parts of the plate boundary. In addition to the basaltic 
magmatism of the extensional environment a significant component of silicic magmatism is also present (Jakobsson et al., 2008; Sigmarsson et al., 2008). Furthermore, several of the volcanoes are sufficiently far away from the plate boundary rift zones to be termed intraplate volcanoes. Being above sea level and moderately populated Iceland therefore offers a suitable laboratory to study a wide range of volcanic phenomena at reasonably close range.

In the 1100 years history of cohabitation with the Icelandic volcanoes several cases have been noted and documented of seismicity immediately preceding volcanic eruptions (Thoroddsen, 1925). The bishop Hannes Finnsson (17391796) even suggested, following the beginning of the Hekla eruption of 1766-1768, that instruments such as barometers and compass needles might be useful, also that paying attention to the intensity and direction of seismic shocks could be used to predict and warn of impending eruptions (Finnsson, 1767), an interesting suggestion more than a century before the invention of seismographs.

When sensitive seismographs became available and were installed in the vicinity of the highly active volcanoes in Iceland it became clear that their eruptions generally have detectable precursors. Seismogrphs have since become an integral part of a monitoring system with the objectives to detect precursory activity and warn against impending eruptions. The seismicity pattern may be divided into two categories, longterm and short-term. The long-term pattern, months to years, is characterized by low-level, persistent seismicity clustered at the volcano, often accompanied by, or caused by inflation of a magma body. The short-term precursory activity, tens of minutes to a few days, is characterized by an intense and growing swarm of small earthquakes, marking the time when increasing pressure in a magma body breaches its walls and a dike starts propagating through the crust. A rapid deflation of the magma body may result. Intermediate-term precursory activity also exists, but is more difficult to define. In this paper the experience of short-term seismic precursors to eruptions in Iceland is summarized. It is shown that all eruptions in the last decades have been preceded by swarms of microearthquakes with precursory times ranging between $15 \mathrm{~min}$ and 13 days. In twothirds of all cases the precursory activity has been identified soon enough to issue a warning prior to the outbreak of an eruption.

\section{TECTONIC SETTING OF ICELANDIC VOLCANOES}

Active volcanism in Iceland is limited to the divergent segments of the mid-Atlantic plate boundary that crosses the island from SW to NE, and a few flank zones that are not directly in the zones of plate divergence (Sæmundsson, 1978; Jakobsson, 1979a; Einarsson, 2008). Some of the volcanoes are therefore tholeiitic and intimately related to the process of plate separation, such as Krafla in the Northern Volcanic Zone (Figure 1) and Grímsvötn and Bárðarbunga in Central Iceland, located in the central area of the Iceland hotspot. Other active volcanoes, such as Hekla, Katla, and Eyjafjallajökull, are located in a flank zone, where transitional alcalibasalts are the main products. The Vestmannaeyjar volcanic system, with the eruptions of Surtsey 1963-1967 and Heimaey 1973, is alcalic.

Volcanological terms used in Iceland may in some instances deviate from the ones used in other areas. This results from the somewhat special circumstances of a subaerial divergent plate boundary. Volcanic structures are exposed on the surface that are usually submerged by ocean and the volcanism often is of areal extent. Walker (1993) used the term central volcano to describe areas of intense volcanism in the Tertiary lavas of Eastern Iceland and found them to be associated with dyke swarms. He used the term volcanic system for the structural unit consisting of a central volcano and a dyke swarm. Sæmundsson (1974) pointed out that the present-day equivalents of the dyke swarms were the fissure swarms commonly found in the neovolcanic zones and defined the active volcanic systems of the volcanic rift zone in Northern Iceland. Later, using the same criteria, he defined the volcanic systems of the whole neovolcanic zone of Iceland (Sæmundsson, 1978). Jakobsson (1979b) established petrological characterisics of most of the systems of South and Central Iceland and showed that they could be distinguished by the chemical composition of their products.

For clarification we define these terms as follows:

Central volcano is an area of high volcanic productivity. Central volcanoes are usually of basaltic composition but often contain a significant quantity of rocks with high silca content such as rhyolite and dacite. A central volcano may have one or more calderas and geothermal systems. A fissure swarm is a collection of many similar, parallel or subparallel fissures and normal faults occurring in a limited area. A volcanic system is a structural and petrological unit consisting of a central volcano and associated fissure swarms.

We note that there is overlap between these terms and terms used elsewhere. The Hawaiian term rift zone, e.g., is almost synonymous with our term fissure swarm. The rift zones of Kilauea, the SW- and E-rift, would be called fissure swarms in Icelandic terminology. An Icelandic rift zone consists of several volcanic systems and would contain several fissure swarms. Also, our term volcanic system is in some cases similar to the term ridge segment used for structural units on the mid-ocean ridges.

Different authors have used different definitions for volcanic systems of Iceland and there is considerable confusion in the literature regarding names. In this paper we follow the classification of Einarsson and Sæmundsson (1987) which is widely referenced.

\section{MONITORING SYSTEMS}

The technical possibilities to detect premonitory changes to eruptions has changed greatly during the last half century and the threshold of detection is lowered throughout the period (Einarsson and Björnsson, 1987). The following periods can be defined: 


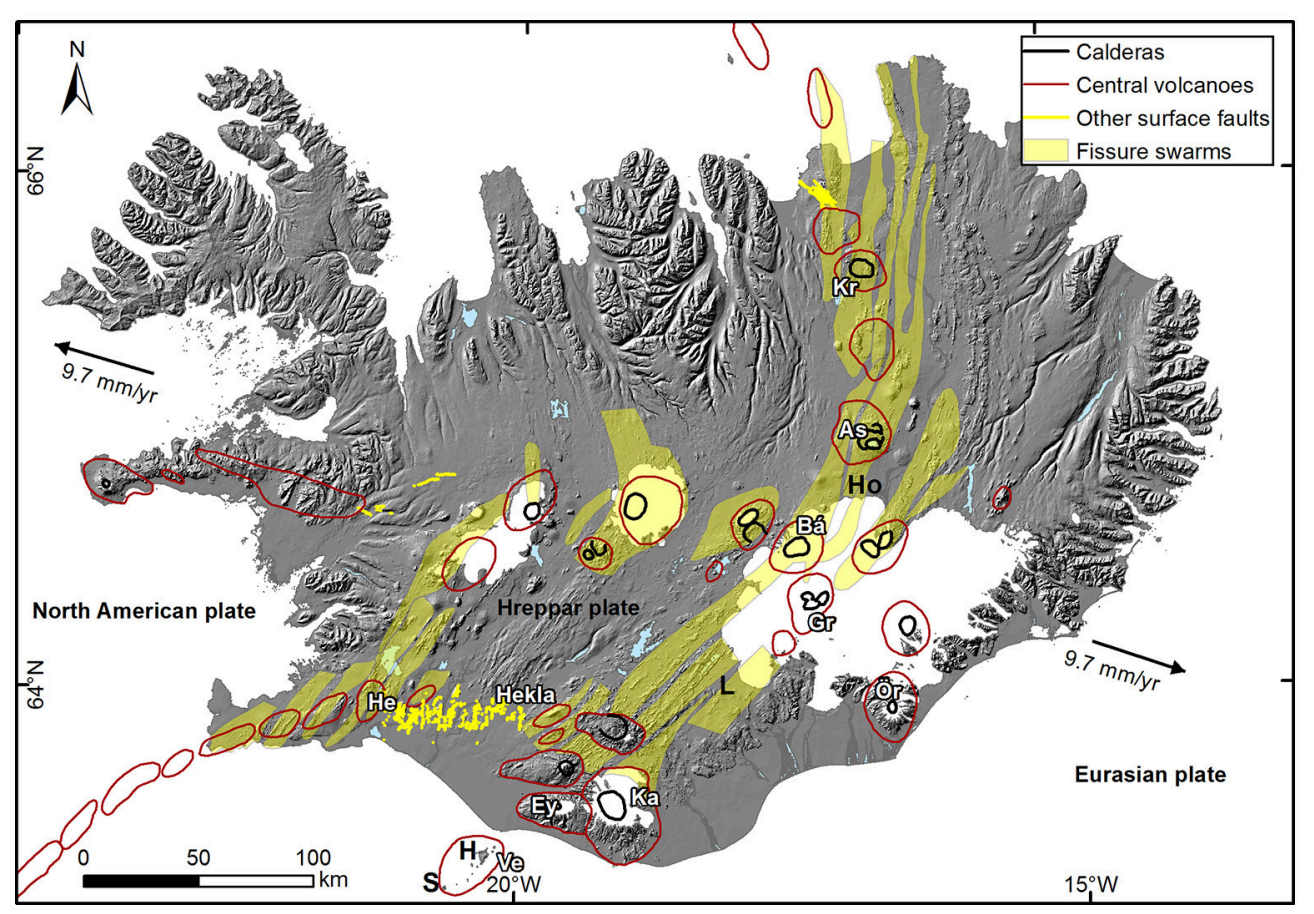

FIGURE 1 | A map showing the neo-volcanic zones of Iceland and the active volcanic systems: Kr Krafla, As Askja, Bá Bárðarbunga, Gr Grímsvötn, Ör Öræfajökull, Hekla, Ka Katla, Ey Eyjafjallajökull, Ve Vestmannaeyjar, He Hengill. Eruption sites are also shown: Ho Holuhraun, H Heimaey, S Surtsey.

Pre-1965: The first seismographs were installed and operated 1909-1914 and then reinstalled in the 1920ies. Although insensitive, they gave an indication of the activity. The sensitivity was greatly improved by the installation of the 6-component WWSSN-station of Akureyri (AKU) in 1964. By then four stations were operated in the country. They were analog stations, recording on photographic paper.

1965-1973: Experiments were done with temporary field seismographs, both to record aftershocks, earthquakes swarms and seismicity associated with volcanoes and geothermal areas. The first experiment was conducted on Surtsey island produced in the eruption of 1963-1967 off the south coast (Einarsson, 1974). Microearthquake surveys were done of the whole country (Ward et al., 1969; Ward and Björnsson, 1971). Temporary seismic networks were operated on the Reykjanes Peninsula (Björnsson et al., in review) and prototype instruments were installed at permanent locations in South Iceland. They detected seismicity associated with the Heimaey eruption of 1973. Parts of the Surtsey eruption and the eruption of Hekla in 1970 were monitored with local seismographs recording on FM magnetic tape.

1973-1991: The number of sensitive seismographs increased greatly in the late 1970ies and a network of 40-50 stations was in in operation throughout the active areas by 1979 . These were one-component, analog seismographs, recording with pen on paper, designed at the Science Institute, University of Iceland. These instruments were used to monitor the progress of the Krafla magmato-tectonic events in North Iceland 1975-1984, the eruptions of Hekla 1980-1981, and Grímsvötn in 1983. This network was extended into the interior of Iceland in 1985, when telemetered seismographs were installed at some of the active volcanoes there.

1991-Present: A new generation of seismographs was introduced in 1991 with the South Iceland Lowland digital network (Stefánsson et al., 1993). This network was expanded to North Iceland in 1994 and at the time of writing more than 60 stations are in operation in Iceland. The network operates semi-automatically and provides preliminary locations and magnitude determination on-line within a few minutes, at http://www.vedur.is/. The SIL-system has detected seismicity associated with the Hekla eruptions of 1991 and 2000, the Gjálp eruption of 1996, the Grímsvötn eruptions of 1998, 2004, and 2011, the Eyjafjallajökull eruptions of 2010, and the Bárðarbunga activity of 2014 onwards. The network has been augmented by local seismograph networks operated in South and Central Iceland since 2005 in cooperation between Cambridge University, Uppsala University, and Icelandic institutions and have provided data for valuable studies of Askja, Eyjafjallajökull, Katla, and Bárðarbunga Volcanoes.

\section{HISTORIC ACCOUNTS OF PRE-ERUPTION SEISMICITY}

As mentioned above, it has been general knowledge in Iceland for centuries that eruptions are preceded by earthquakes. Bishop Hannes Finnsson compiled some of the historical, written 
documents and Thoroddsen (1925) continued his work. In the pre-instrumental era the known cases are limited to those where earthquakes were felt prior to the beginning eruptions. Out of 18 large, historic eruptions of Katla (Thorarinsson, 1975), nine were accompanied by felt earthquakes according to written documents. This does not mean that the other nine were not accompanied by earthquakes also, but they are not mentioned. In the eruptions of $1311,1625,1721,1823,1860$, and 1918 it is specifically stated that the felt earthquakes occurred well before the eruption was seen, from a couple of hours to several days. Hekla shows a very different behavior. The generally low seismic activity associated with Hekla eruptions is remarkable. Exceptions are the eruptions in the Hekla volcanic system outside the main edifice, such as the eruptions of 1554, 1725, 1878, and 1913 (Thorarinsson, 1967b). The last two, at least, were lava eruptions issuing from eruptive fissures, and may have a strong tectonic component. The rifting episodes of Krafla 17241746, the Grímsvötn system in 1783-1785 (Laki Fires), and Askja in 1874-1876 were accompanied by felt earthquakes, also the Öræfajökull eruptions of 1362 and 1727. The historical reports of these events are compiled by Einarsson (in preparation 2018).

\section{INSTRUMENTAL OBSERVATIONS, CASE HISTORIES}

\section{Surtsey}

The first seismic recording of a beginning of an eruption in Iceland at a close range was obtained during the Surtsey eruption of 1963-1967. The eruptive activity began in November 1963 on the ocean bottom at the southern tip of the Eastern Volcanic Zone (e.g., Thorarinsson, 1964, 1965, 1966, 1967a, 1968; Thorarinsson et al., 1964), and continued until June 1967. It was divided into phases, separated by short quiet intervals. Three islands were formed but two were eroded down below sealevel in a few months. One of the phases ended on August 101966. On August 19a new eruptive fissure opened up on the island of Surtsey. Three lava craters were active in the beginning but a few days later only one remained. Lava was erupted from this crater until June 5, 1967, building up a flat lava shield and extending the Surtsey island to the east. A small array of seismometers was in operation on the island when this lava eruption started (Einarsson, 1974) recording on an FM-magnetic tape. It recorded a swarm of small, very local earthquakes that began at 09:30 $\mathrm{h}$ (Figure 2). None of these events were felt on the island. The swarm ended by 10:30 h and shortly thereafter the amplitude of the background noise increased slowly. The noise increased rapidly at 10:50 $\mathrm{h}$ and it is inferred that this marks the beginning of the eruption. The eruption was not discovered until about $2 \mathrm{~h}$ later by the watchman on the island. This sequence of events has all the characteristics of precursory seismicity, i. e. a swarm of small earthquakes that ends before or about the time of the beginning of the eruption, and followed by eruption tremor.

\section{Heimaey}

An eruption started on January 23, 1973, between 01:50 and 01:55 h on the island Heimaey in the Vestmannaeyjar volcanic system, only $200-300 \mathrm{~m}$ east of the town of 5,300 inhabitants
(Thorarinsson et al., 1973). The eruption was preceded by an earthquake swarm 30-14 h before the outbreak (Björnsson and Einarsson, 1974). A few events that occurred immediately before the outbreak were felt in the town. Other precursors were not reported. Within a few minutes the NNE-striking eruptive fissure was 300-400 $\mathrm{m}$ long. A length of about $3 \mathrm{~km}$ was attained on January 25 and was extended to the north an additional half kilometer on February 6. The earthquake swarm preceding the outbreak was recorded by prototype seismographs on the mainland but could not be located accurately. Later, during the eruption, when more seismographs had been installed, both on the mainland and the island of Heimaey, earthquakes could be located with fairly good accuracy. They turned out to occur at larger depth than had been seen before in Iceland, 15-25 km (Einarsson, 1991a). The similar waveforms of these later events suggest that the precursory earthquakes were also located at this relatively large depth.

\section{Krafla}

The volcano-tectonic episode that took place in the Krafla volcanic system in 1974-1989 was a source of many data sets and observations on the relationship between crustal movements, seismic activity and magmatism. The episode included at least 20 deflation events of the Krafla volcano, when an inflating magma chamber at about $3 \mathrm{~km}$ depth beneath the caldera was breached and magma was injected into the adjacent fissure swarms (e.g., Björnsson et al., 1977; Tryggvason, 1984; Einarsson, 1991b; Brandsdóttir and Einarsson, 1992; Buck et al., 2006; Heimisson et al., 2015). The magnitude of these deflation events was quite variable, from being barely measureable to amounting to $2 \mathrm{~m}$ of subsidence in the center of the caldera. Nine of these dike injections found their way to the surface and produced lava eruptions in the rift zone (Sæmundsson, 1991). Warnings were issued prior to all the eruptions except the first one. The eruptions were:

1975, December 20: The first and largest of the deflation events began rather abruptly after a few months of elevated seismicity in the caldera. An intense earthquake swarm began at 10:17 merging into continuous vibrations of the ground. This activity was detected on seismic stations across the whole of Iceland. About 15 min later a small lava eruption broke out at the center of the caldera. Report of this activity came from various directions, both about the visible eruption and the detected seismicity. A warning came only after the eruption had been sighted, however. The eruption was very small and only lasted about $2 \mathrm{~h}$. It stopped when dikes propagated laterally out of the caldera, as shown by propagating earthquakes. The dike intrusion lasted almost 3 months and the dike attained a length of $60 \mathrm{~km}$.

1977, April 27: Following three diking events and reinflation a new and rapid deflation event began at 13:17 accompanied by tremor and an earthquake swarm. The earthquakes propagated along the southern fissure swarm of Krafla and were accompanied by large scale surface rifting. Small eruptions occurred in two locations during this swarm, one in the center of the caldera and a small lava patch at the northern caldera rim. Because of a snow storm this day the timing of the eruptions is not accurately known. Warnings were issued to the 


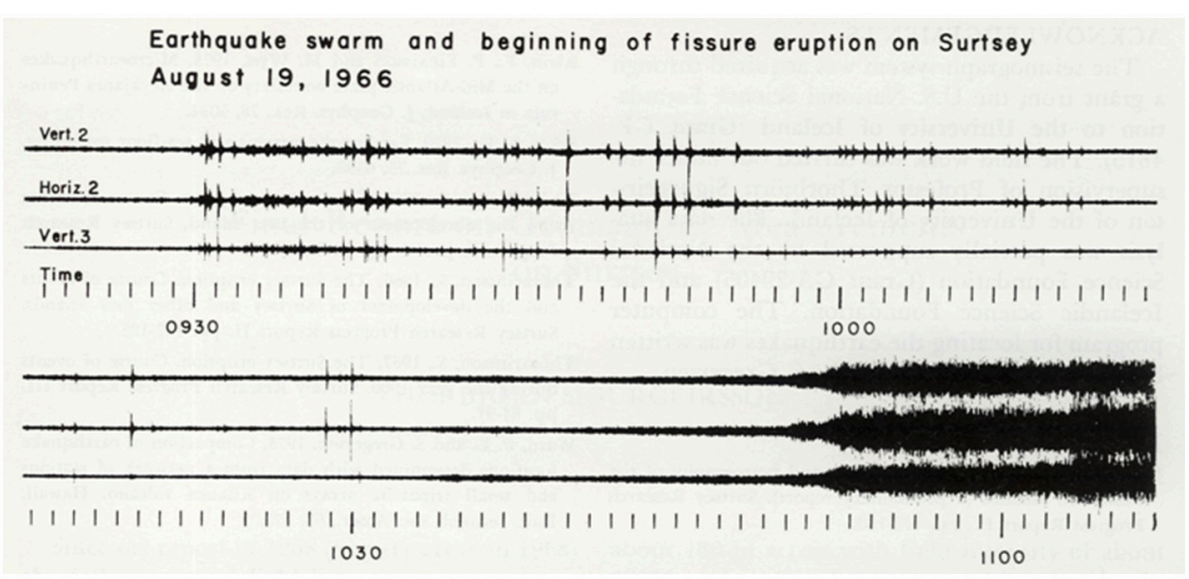

FIGURE 2 | Seismograms from three components of a small array operated on Surtsey island in 1966, showing the time interval 09:22-11:07 on August 19, when a new lava eruption broke out on the island (from Einarsson, 1974). Reproduced with the permission of the copyright holder, the Surtsey Research Society.

local population almost instantly, so it was almost certainly issued prior to the eruption outbreak.

1977, September 8: A new deflation event began with rapid subsidence of the caldera and earthquakes at 15:47. A small eruption broke out at the northern caldera rim about $18 \mathrm{~h}$. The eruption ended rather abruptly, however, when earthquakes began propagating out of the caldera into the southern fissure swarm (Brandsdóttir and Einarsson, 1979). Warnings about a possible eruption were issued well before the eruptions broke out. In addition, the dike led to a small magmatic eruption through a geothermal drillhole in the southern fissure swarm (Björnsson and Sigurðsson, 1978), the only known magmatic eruption through a man-made structure.

1980, March 16: Rapid deflation and tremor mixed with earthquakes began at 15:17. The tremor increased markedly half hour later, and an eruption began slightly north of the center of the caldera at 16:20. The eruptive fissure extended northwards and in $25 \mathrm{~min}$ it had attained a length of $4.5 \mathrm{~km}$. Earthquakes continued propagating northwards and then also southwards out of the caldera. The diking activity led to a pressure drop and eventually to an end to the eruption, first at the southern end of the fissure. The eruption was over by 22:30. The seismic activity was noticed immediately by the attendant of the instruments and information about the progress of the activity was distributed to the local community and the media.

1980, July 10: Slow deflation began according to tiltmeters at about $8 \mathrm{~h}$ in the morning. One hour later weak tremor was detected on the seismographs. Small earthquakes indicated propagation to the north. Tremor amplitude and earthquakes became larger as time went on. A low-frequency event was detected at noon and an eruption was finally verified in the fissure swarm north of the caldera at 12:53. Both the tremor and the earthquake activity diminished significantly when the eruption broke out. This eruption continued for 8 days and was much larger than any of the previous eruptions. No lateral diking was observed after the beginning of the eruption. Subsequent three eruptions were similar in magnitude. The local population and the media were kept well informed during the whole course of these events.

1980, October 18: The course of events in this eruption was quite a bit faster than in the previous eruption. Deflation began at 20:42 and tremor was detected a few minutes later. The deflation rate and earthquakes increased rapidly and were higher than ever in previous events. A low-frequency event was detected at 21:45 and $19 \mathrm{~min}$ later an eruption was seen about $2 \mathrm{~km}$ north of the center of the caldera. The eruptive fissure extended quickly to the north and south until it attained a length of $7 \mathrm{~km}$. The vigor of the eruption then slowly diminished until the eruption came to an end on October 23.

1981, January 30: Slow deflation began at $7 \mathrm{~h}$ and became gradually faster. Tremor was detected half hour later (Figure 3). Deflation rate and tremor amplitude culminated about $9 \mathrm{~h}$ and then slowly decreased. A low-frequency earthquake was detected at 13:13 and following that the earthquake activity slowly decreased. An eruption broke out on a $2 \mathrm{~km}$ long fissure in the fissure swarm north of the caldera at 14:10. This eruption ended on February 4.

1981, November 18: Rapid deflation began at 00:36 accompanied by tremor, both increasing fast, culminating between 01:15 and 01:35. The first low-frequency earthquake was detected at 01:38 and an eruption broke out at 01:52. The first eruption site was about a kilometer north of the center of the caldera, but the fissure quickly propagated both south- and northwards until it reached $8 \mathrm{~km}$ length at about $4 \mathrm{~h}$. The eruption vigor then slowly decreased until the eruption came to an end on November 23.

1984, September 4: The inflation rate was high in the first month following the 1981 November eruption. It then slowed down and became irregular as the level of inflation exceeded the previous maximum. This condition remained until a new deflation event began at 20:25 on September 4, 1984. Tremor was detected at the local seismic stations at 20:40 and earthquake activity increased, mostly between 22 and $23 \mathrm{~h}$ (Figure 4). The 


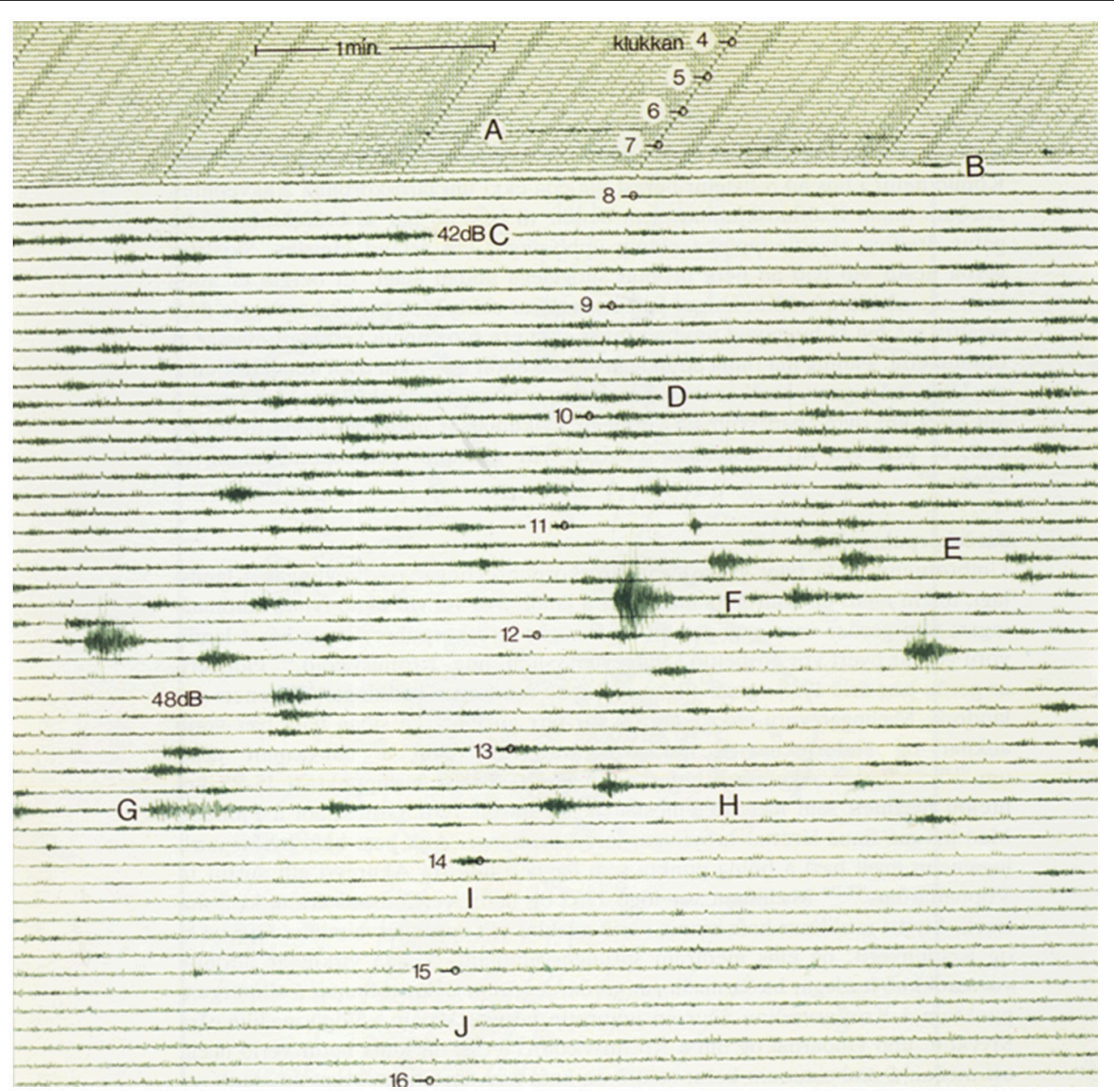

FIGURE 3 | Seismic precursory activity to the Krafla eruption on January 30, 1981, as seen on the seismogram from Reynihlíd, about 10 km SSW of the caldera center. Only 40\% of the seismogram is shown. Numbers show the hour-marks. A marks a passing car, B beginning of the spasmodic tremor, D typical spasmodic tremor, $\mathrm{E}$ and $\mathrm{F}$ increasing high-frequency earthquake activity, G low-frequency earthquake, $\mathrm{H}$ earthquake activity decreases, eruption begins at 14:10, I and $\mathrm{J}$ mark low-frequency tremor. From Einarsson (1991b). Reproduced with the permission of the copyright holder, the Icelandic Natural History Society.

first low-frequency earthquake was detected at 23:40. Nine 9 min later (at 23:49) the flare of an eruption was seen. The eruption began almost simultaneously on two fissure segments on either side of the northern caldera rim. The segments grew in length and new segments became active until a continuous wall of fire was active, $8.5 \mathrm{~km}$ in length, extending northwards from the center of the caldera well into the northern fissure swarm. The eruption followed similar course as previous eruptions for the first 3 days, slowly diminishing until only one crater was active. On September 7 there was a change in course. The lava flow rate from this crater began increasing day by day, accompanied by increasing deflation rate of the caldera. This increase continued until September 18, when the eruption came to a sudden end. This eruption was by volume the largest eruption of the whole series.

The volcano began inflating after this last eruption of the episode and eventually reached the pre-eruption inflation level after several years. No inflation has been detected since 1989. The total volume of erupted lava is difficult to estimate because of the extensive changes in topography associated with the rifting. Values in the range 250-350 $\mathrm{Mm}^{3}$ seem reasonable. Volume of intruded magma during the whole rifting episode is probably larger, possibly much larger.

\section{Hekla}

Seismic observations are available for the 1970, 1980-1981, 1991, and 2000 eruptions of Hekla. The precursory seismic activity for all these eruptions is similar in many ways. No long-term changes have been identified (Soosalu and Einarsson, 2005). Short-term changes were recorded 23-79 min before the outbreak of the eruptions. This short precursor time appears to be inconsistent with the large depth of 15-20 km to the feeding magma reservoir (Soosalu and Einarsson, 2004; Ofeigsson et al., 2011; Geirsson et al., 2012). Sturkell et al. (2013) discuss this in connection with their finding that the surface eruptive fissure only extends 


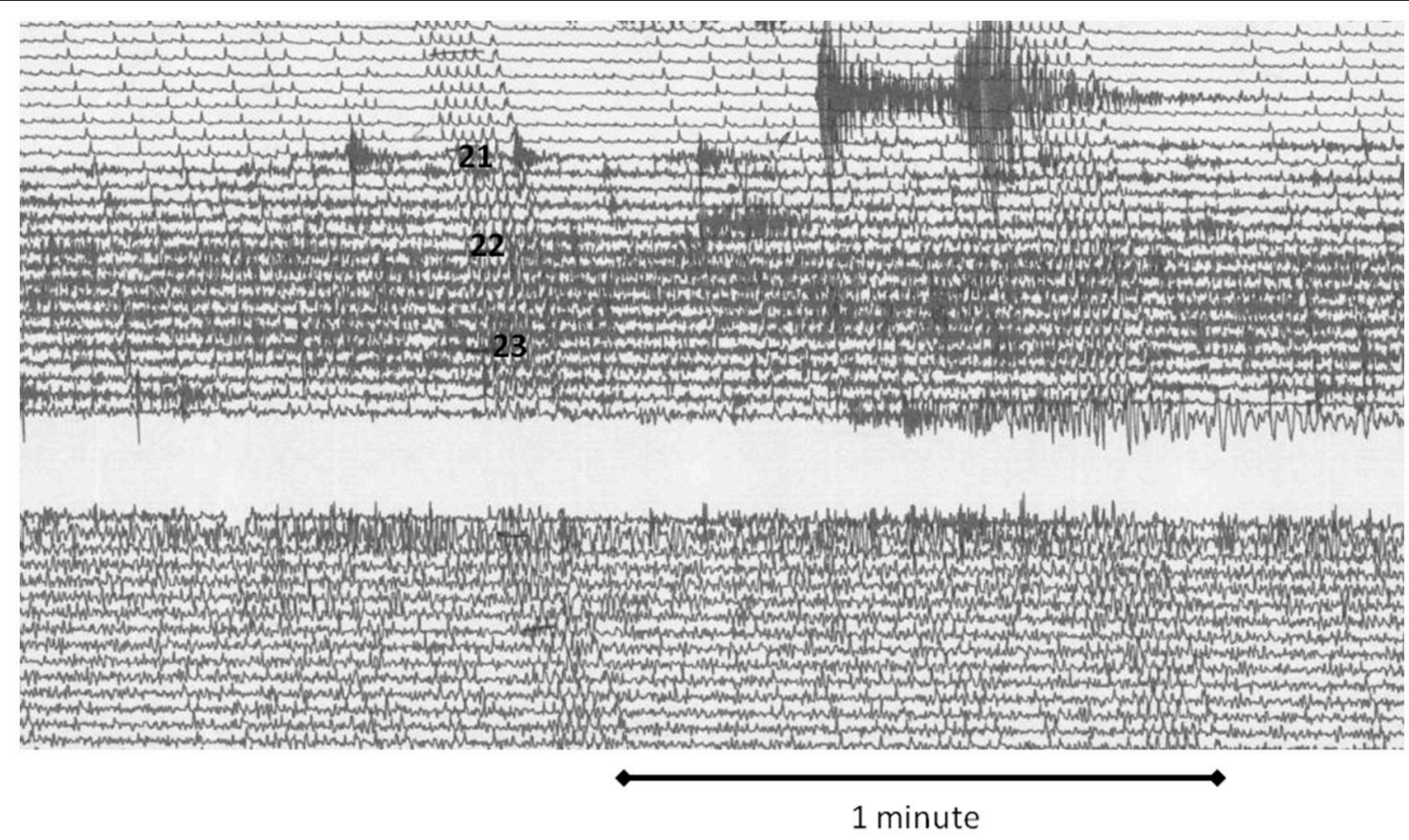

FIGURE 4 | The beginning of the September 1984 Krafla eruption seen at the seismic station of Skinnastaður, $40 \mathrm{~km}$ north of the eruption site. Only a section of the seismogram is shown. The earthquake near the top of the seismogram was a magnitude $2.9\left(\mathrm{M}_{\tau}\right)$ event in the Tjörnes fracture zone in Fljót, unrelated to the eruption. At this station high-frequency tremor mixed with earthquakes is seen at 22:50. The beginning of the eruption at 23:49 is not accompanied by a significant seismic event. The eruption was accompanied by low-frequency tremor, but very few earthquakes.

to shallow levels in the crust, below which a pipe-like conduit extends downwards to the reservoir. The conduit remains fluid between eruptions. The short precursor time then represents the travel time of magma from the top of the conduit to the surface and not the propagation of a dike from a deep reservoir.

1970, May 5: The eruption began at 20:23 according to eyewitnesses in two areas on the lower flanks (Thorarinsson, 1970; Thorarinsson and Sigvaldason, 1972). The precursory earthquake swarm is exemplified by the seismogram of the AKU station (Figure 5) in North Iceland, at a distance of $200 \mathrm{~km}$ from Hekla, recording the beginning of the eruption. Small earthquakes become visible at 19:58, then gradually becoming larger and more frequent (Einarsson and Björnsson, 1976). This eruption lasted until July 5.

1980, August 17: The first earthquakes were recorded by a short-period seismograph at $22 \mathrm{~km}$ distance at 13:04 h on August 17 (Grönvold et al., 1983). The eruption outbreak was timed at 13:27, which was also the time when continuous, low-frequency tremor became visible on the seismograms. The eruption was relatively intense in the first day but declined rapidly and was over by August 20. Activity was renewed on April 9, 1981, and low-level activity continued for about a week. This activity was accompanied by continuous tremor of low amplitude, but only a few small earthquakes.

1991, January 17: The precursory activity to the 1991 eruption (Gudmundsson et al., 1992) was recorded by many seismographs, both analog, telemetered stations in the highlands to the $\mathrm{E}$ and NE of the volcano and a new, digital network, the SIL-network,
$\mathrm{W}$ of Hekla. The earthquake swarm began at 16:30 (Figure 6) with small events, which quickly became larger until the eruption broke out between 17:00 and 17:02 (Gudmundsson et al., 1992; Linde et al., 1993; Soosalu and Einarsson, 2002; Soosalu et al., 2003). The recorded seismic activity was detected by people before the eruption was seen, but only after the eruption had already started. The eruption was most intense during the first hours and then gradually diminished in intensity and ended on March 11.

2000, February 26: The beginning of the 2000 eruption is the best documented one. A short-period, telemetered, analog station operating on the flank of the volcano was being attended when the precursory swarm began with tiny earthquakes at 17:00 (Soosalu et al., 2005). Because of the unusual occurrence of earthquake swarms near Hekla, the activity was immediately taken as a possible precursory signal. Less than 20 min later the Civil Defense Authorities had been notified of a likely outbreak of a Hekla eruption. The beginning of the eruption was timed accurately at 18:19 h by an eyewitness interview over telephone, broadcast life on the National Radio. This eruption ended on March 8.

\section{Grímsvötn}

The mostly subglacial Grímsvötn volcano in Central Iceland is known as the most frequently erupting volcano of Iceland. Following a small eruption in 1934, however, it went into a quiet state for almost half a century (Björnsson and Einarsson, 1990; Guðmundsson and Björnsson, 1991; Guðmundsson et al., 


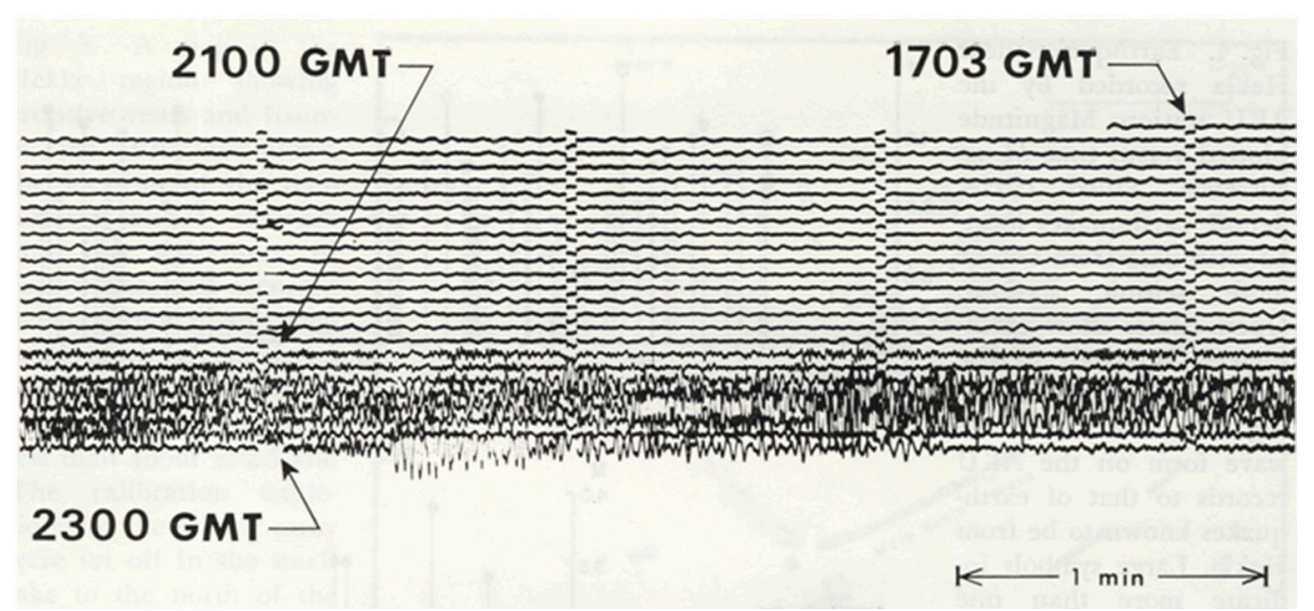

FIGURE 5 | Seismogram of May 5, 1970 from the vertical, short-period seismograph at the WWSNN-station at Akureyri, $200 \mathrm{~km}$ N orth of Hekla, showing the seismic activity associated with the beginning of the eruption of the volcano. From Einarsson and Björnsson (1976). Reproduced with the permission of the copyright holder, Jökull.

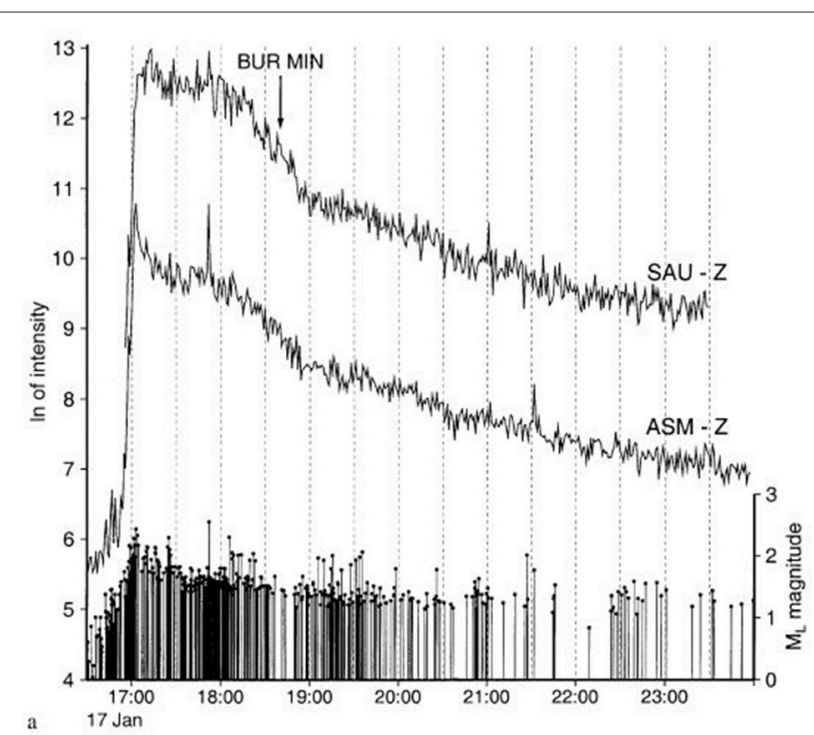

FIGURE 6 | Seismicity associated with the beginning of the Hekla eruption of 1991. Plot of tremor amplitude (top) at two seismograph stations in South Iceland, SAU and ASM, and the magnitude of earthquakes at Hekla (bottom). From Soosalu et al. (2003). Reproduced with the permission of the copyright holder, Springer Nature.

1995). Small eruptions of 1983, 1998, and 2004 were followed by a relatively large eruption of 2011. All these four recent eruptions were preceded by detected seismic precursory activity and warnings were issued prior to the outbreak of two of them.

1983, May 28: The eruption was preceded by a significant increase in seismic activity for about 3 months (Einarsson and Brandsdóttir, 1984). An intense swarm began with an M 2.9 event at 02:30 on May 28. The swarm lasted about $9 \mathrm{~h}$ and was followed by continuous tremor, first seen at about $12 \mathrm{~h}$ at the nearest seismograph, at a distance of $65 \mathrm{~km}$ from Grímsvötn.
The eruption is inferred to have begun between the time of the last earthquake, at 11:47, and the appearance of the continuous tremor. It was not verified visually until the next day, due to the remoteness of Grímsvötn. The eruption lasted 5 days.

1998, December 18: The 1998 eruption was preceded by elevated seismicity for several months, apparently due to inflation of the volcano, consistent with GPS-measurements on the southern caldera rim (Sturkell et al., 2003a). A temporary study by Alfaro (2001) revealed vigorous seismic activity along the western and southern caldera rim during a recording period from late May to August 1998. A small earthquake swarm began on December 17 at about $22 \mathrm{~h}$ and a sharp increase in earthquake activity was recorded at 03:30 on December 18. Continuous tremor with volcanic characteristics was recorded at 09:20, marking the beginning of eruptive activity. The long-term restless state of Grímsvötn was recognized before the eruption, but the short-term precursory activity was first identified after the beginning of the eruption. The eruption column rose to $10 \mathrm{~km}$ height in $10 \mathrm{~min}$ and began to decline the following day and ended on December 28.

2004, November 1: The eruption of Grímsvötn volcano in 2004 was forecast on several different timescales. Inflation of the volcano began immediately after the 1998 eruption and was monitored by GPS measurements on the caldera rim. Seismic activity began increasing in July 2003 and by September 2004 the inflation level of the volcano had reached the 1998 pre-eruption level (Vogfjörd et al., 2005; Sturkell et al., 2006). It became public knowledge that a Grímsvötn eruption was imminent. At this time it also became known that the lake level in the Grímsvötn caldera was rising beyond the critical level for a jökulhlaup, a situation that could possibly trigger an eruption by sudden release of pressure on the magma system. The beginning of a jökulhlaup was detected on October 27 by high-frequency tremor on regional seismographs. The flood was detected on the lowland 2 days later. An announcement was given for increased 
probability of an eruption within a few days. A dense swarm of small earthquakes began in the early hours of November 1 signifying magma propagating toward the surface. The swarm intensified at 19:30 and by $20 \mathrm{~h}$ the activity was dominated by volcanic tremor (Figure 7), indicating the beginning of an eruption. This was a relatively small eruption. The maximum plume height of $12 \mathrm{~km}$ was measured a few hours after the beginning, and by November 3 the plume disappeared from radar. The eruption appears to have ended on November 6 .

2011, May 21: This largest eruption of Grímsvötn for at least a century followed a period of inflation that began immediately after the 2004 eruption. Increasing seismic activity accompanied the inflation from 2009 onwards. A dense earthquake swarm began on May 21, 2011, at about 17:50 and an eruption began around $19 \mathrm{~h}$ (Hreinsdóttir et al., 2014). The eruption column reached a height of more than $20 \mathrm{~km}$ during the first hour, the tallest for several decades in Iceland. It occasionally reached height of 10-12 km during the following days, but then decreased fast. The eruption was over by May 28. A warning was issued well before the beginning of the eruption.

\section{Gjálp}

1996, September 30: The subglacial Gjálp eruption occurred on a 7-km long eruptive fissure between the calderas of Bárðarbunga and Grímsvötn and was preceded by several years of unrest, both earthquakes and jökulhlaups from glacial cauldrons (Einarsson et al., 1997). The immediate precursory activity was rather unusual, apparently triggered by an earthquake of magnitude 5.4 (Ms) at 10:48 on September 29 on the northern caldera rim of Bárðarbunga. Similar earthquakes had occurred 14 times before, in a sequence that began in 1974 (Einarsson, 1991a), and every event had been followed by seismic quiescence. This time, however, the earthquake was followed by an intense swarm of smaller events in the caldera that continued through September 29 and 30 and propagated southwards, out of the caldera and toward the Grímsvötn volcano (Einarsson and Brandsdóttir, 1997). A warning was issued that Bárðarbunga might be about to erupt, based on the intensity of the swarm and its unusual course of events. Tremor with characteristic low-frequency appeared on the seismograph at Grímsvötn in the evening of September 30 indicating the beginning of an eruption. Visual confirmation came the following morning when large cauldrons in the ice surface were seen from an overflying aircraft. The glacier in the area is $400-600 \mathrm{~m}$ thick and it took the eruption about $60 \mathrm{~h}$ to melt through the ice to form an eruption column. The eruption lasted until October 13 and formed about $0.5 \mathrm{~km}^{3}$ of basaltic andesite (Guðmundsson et al., 1997; Gudmundsson et al., 2004).

\section{Bárðarbunga}

2014, August 29: In terms of erupted volume this was the largest eruption in Iceland since the Laki eruption in 1783. The eruption was preceded by a lateral dike propagation from the caldera of Bárðarbunga that began on August 16 and was identified that day (Sigmundsson et al., 2015). The progress of the dike was monitored by its associated earthquakes and crustal movements caused by volume changes of the dike. The volume loss beneath the caldera caused collapse of the caldera floor that could be monitored by a GPS-station on the glacier surface within the caldera (Gudmundsson et al., 2016). The dike propagated for more than $45 \mathrm{~km}$ at variable rate before a small eruption broke out at its distal end on August 29, in the Holuhraun area of Central Iceland, 13 days after the initial breach of the

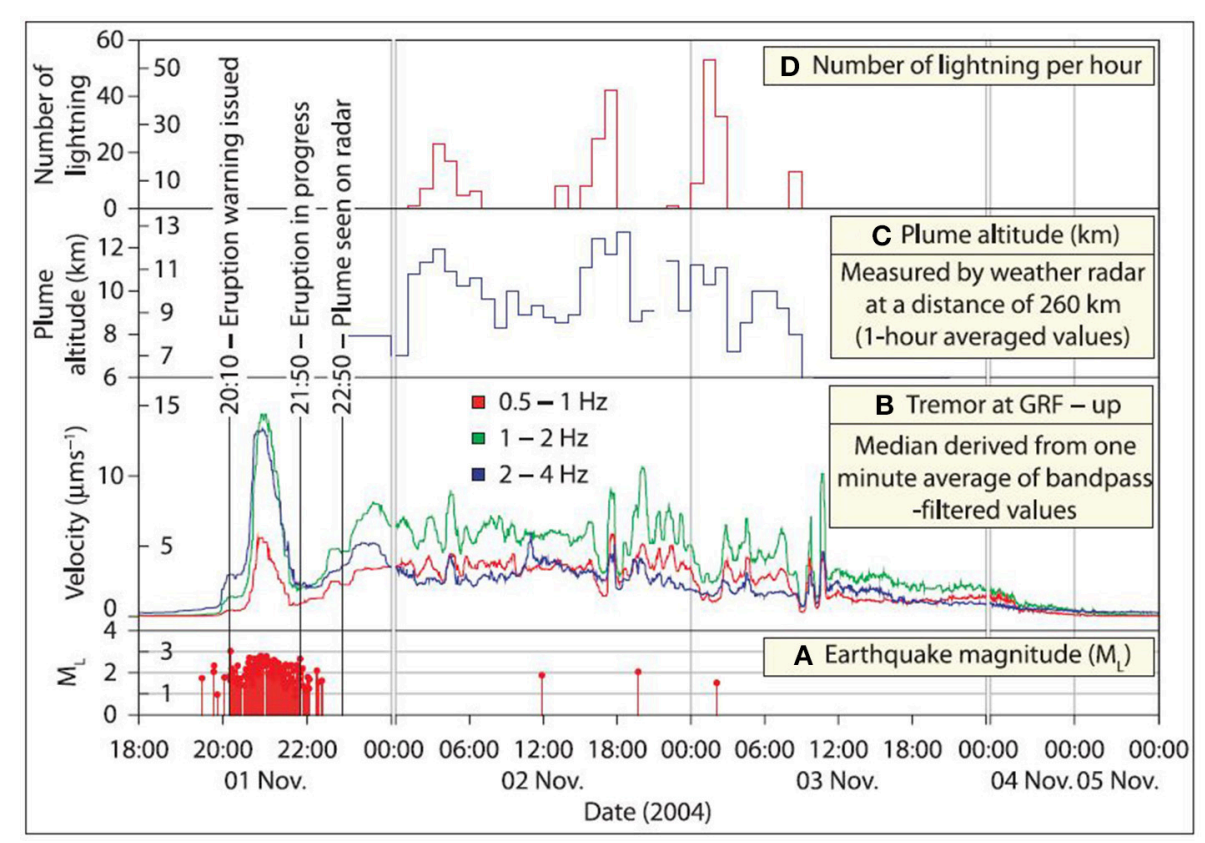

FIGURE 7 | The time line of the Grímsvötn 2004 eruption. From Vogfjörd et al. (2005). Reproduced with the permission of the copyright holder, Kristín Vogfjörð. 
magma storage beneath the caldera. This eruption lasted only $4 \mathrm{~h}$. Another eruption broke out on August 31 on the same fissure. This eruption lasted until the end of February 2015. The eruptions were preceded by the formation of a narrow graben above the dike near the eruption site (Hjartardóttir et al., 2016). This long "short-term" precursor to the eruptions was detected and identified very quickly and aroused public attention and alert during the whole propagation process.

\section{Eyjafjallajökull}

2010, March 20: Following 18 years period of unrest, including 3 intrusions in 1994, 1999, and 2009 of several months' duration each (Pedersen and Sigmundsson, 2004, 2006), a small lava eruption broke out on the eastern flank of the volcano, at Fimmvörðuháls (Sigmundsson et al., 2010). The eruption immediately followed the fourth intrusion that began in early January 2010 accompanied by escalating seismicity, more intense than in any of the previous episodes. An eruption was anticipated but the time scale was uncertain. Earthquake hypocenters were propagating toward the eastern flank but the premonitory seismic signal was rather weak. When the eruption finally broke out it was first spotted visually by local inhabitants. The eruption continued with low-level fire fountains for 3 weeks, and produced a small lava field extending into the gullies on the NE flank. The eruption ended rather abruptly on April 12. The volcano did not deflate during the eruption, indicating that it was fed by magma directly from deep sources.

2010, April 14: The sudden end of the flank eruption suggested that the magma feeding channel had been blocked or breached, and further activity might be expected. This came sooner than anticipated. A new eruption broke out shortly after midnight on April 14 and this time in the summit region of the volcano (e.g., Guðmundsson et al., 2010). It was preceded by a distinct increase in earthquake activity beneath the summit caldera. The beginning of the eruption appears to have been very subtle and was only detected by low-amplitude volcanic tremor at 01:15. No further signs of the eruption were seen until 06:50. Then a pulse of tremor was recorded, a considerable body of water was released from the summit caldera and the eruption broke through the glacial cover. The eruptive column reached a height of $10 \mathrm{~km}$ in the first day.

This summit eruption lasted 39 days (Gudmundsson et al., 2012) and spread ash widely, including the European continent where it blocked air traffic for several days.

\section{SEISMIC CRISES WITHOUT SUBSEQUENT ERUPTIONS}

The most common short-term precursory activity to eruptions is due to a dike propagating away from an inflated magma chamber, the seismicity at the dike tip and the sudden pressure drop in the chamber. During the propagating phase it is usually uncertain whether or not the dike will reach the surface. A good proportion of all dikes does not, and yet the geophysical signals are identical to those preceding an eruption. The warning issued prior to eruptions therefore has to include the possibility that the dike might not lead to an eruption. This was the case in the
Krafla rifting episode 1975-1984. At least 20 deflation events of varying size occurred, only nine of which included an eruption. Warnings were issued at the onset of all the events except the first one. A warning without eruptions can hardly be called "false alarm," however. Some of the intrusive events had more serious consequences than most of the eruptions, and a warning was of great importance to the population of the area. Significant diking events without eruptions occurred in September and October 1976, January 1977, January, July, and November 1978, May 1979, February and December1980 (Einarsson and Brandsdóttir, 1980; Einarsson, 1991b; Buck et al., 2006; Wright et al., 2012). In a few instances it was observed that the pressure drop associated with a dike propagation stopped an eruption that had already begun. This happened in December 1975, April and September 1977, and March 1980, see above. In all these cases an eruption began within the caldera shortly after the intial dike intrusion started, but stopped abruptly when the dike propagated out of the caldera.

The Eyjafallajökull eruptions of 2010 were preceded by 18 years of unrest. During this time three sill intrusions were detected without an eruption, in 1994, 1999, and 2009. These events were slow, lasted a few months each and were accompanied by uplift of the volcano and seismicity (Dahm and Brandsdóttir, 1997; Sturkell et al., 2003b; Pedersen and Sigmundsson, 2004, 2006; Hjaltadóttir et al., 2015). No intense swarms were observed, however, and there was never a question of whether a warning of an impending eruption should be issued. The fourth intrusion began toward the end of 2009 and was more intense than the previous three. It intensified greatly in February and March 2010 and finally culminated with the outbreak of the flank eruption on March 20, see above (Sigmundsson et al., 2010).

Historically among the most active volcanoes of Iceland, the Katla volcano requires a special mention. The caldera of the volcano, where all its eruptions have taken place in the last thousand years, is covered by a thick glacier. It takes a large eruption to melt through the ice to produce a subaerial eruption and an eruption column. Such eruptions have occurred about twice per century, each time accompanied by a catastrophic flood and destruction. The latest such eruption occurred in 1918 and the current quiet interval is the longest in historic times. At least three events have taken place, however, during which cauldrons have been formed in the ice cover of the volcano and floods have issued from the glacier edge. These occurred in 1955 (June 25), 1999 (July 18), and 2011 (July 8-9), and were accompanied by earthquakes and seismic signals that resemble volcanic tremor (Tryggvason, 1960; Einarsson, 2000; Gudmundsson et al., 2000; Sgattoni et al., 2017). No eruptive products were seen above the ice surface and therefore these events fall into the category of uncomfirmed eruptions. If these were eruptions, the times of their beginning are unknown. The precursory times can therefore not be determined. The 2011 event was studied in considerable detail. It was preceded by a peculiar sequence of small earthquakes that clustered on the southern flank of the volcano and continued for several years after the event (Sgattoni et al., 2016). Two kinds of contiuous tremor were identified, one associated with the water flood that issued from the glacier, the other originated near the two ice cauldrons where the flood originated (Sgattoni et al., 2017). The event was followed by 
increased earthquake activity in the caldera (Sgattoni et al., in review).

In addition to the confirmed eruptions listed above, there have been many sub-glacial events that resemble eruptions, but were not large enough to break through the ice cover, similar to the events in 1999 and 2011 at Katla. This includes a burst of tremor in the Grímsvötn caldera in 1984 (Einarsson and Brandsdóttir, 1984; Björnsson and Einarsson, 1990), tremor burst and a jökulhlaup at Hamarinn, NW of Grímsvötn in July 2011, and several tremor bursts following jökulhlaups from the Skaftá cauldrons NW of Grímsvötn (e.g., Einarsson et al., 1997; Soosalu et al., 2006).

Increased seismic activity and slow land uplift of the Hrómundartindur volcanic system at the Hengill Triple Junction in SW-Iceland indicated magma flow into the roots of the volcanic system at about $6 \mathrm{~km}$ depth (Sigmundsson et al., 1997; Feigl et al., 2000; Clifton et al., 2002; Pedersen et al., 2007). Slow uplift continued for more than 4 years, reaching $8 \mathrm{~cm}$ at the apex (Feigl et al., 2000). The volume of injected magma may be estimated $15 \mathrm{Mm}^{3}$. Earthquakes of magnitude 5 occurred at the perifery of the uplifted area in June 1998 and $10 \mathrm{~km}$ farther south in November 1998 (Rögnvaldsson et al., 1998). The activity then faded away without any indication of propagating dikes.

Evidence of a dike injection in the lower crust was provided by elevated seismicity and surface uplift at the hyaloclastite mount Upptyppingar in the Northern Volcanic Zone in 20072008 (e.g., Jakobsdóttir et al., 2008; Hooper et al., 2011; White et al., 2011). The distribution of hypocenters and the surface uplift field were consistent with the intrusion of an inclined dike or a sheet, at a depth of $15-25 \mathrm{~km}$, with a dip of about $45^{\circ}$ and striking transversely to the rift zone. The slow intrusion lasted about 1 year and ended without an extrusion to the surface.

\section{DISCUSSION}

Even though it has been general knowledge in Iceland for centuries that the outbreak of volcanic eruptions is commonly associated with earthquakes, it wasn't until sensitive seismographs were installed in Iceland and had been in operation for a few decades that it became clear that all eruptions are preceded by characteristic seismicity, eathquakes and continuous tremor. All cases compiled in the present study confirm this conclusion. The long-term pattern is characterized by low-level, persistent seismicity clustered at the volcano, often accompanied by, or caused by slow stress changes due to inflation of a magma body. The short-term precursory activity, on the other hand, is clearly distinguishable. It is characterized by an intense and growing swarm of small earthquakes, marking the time when a dike starts propagating through the crust. This general theme may have different expressions depending on many parameters, s.a. depth of the magma body in the crust, regional tectonic stress, viscosity of the magma, rate of prior pressure increase etc. We find that the precursor time of the 21 eruptions is highly variable, between $15 \mathrm{~min}$ and 13 days, see Table 1 . Half of the observed precursor times were shorter than $2 \mathrm{~h}$. The times are even quite variable for the same volcano. The nine Krafla eruptions during the rifting episode 1975-1984 had precursor times that varied between $15 \mathrm{~min}$ and $7 \mathrm{~h}$. Precursor times for the four Grímsvötn eruptions varied between $90 \mathrm{~min}$ and $15 \mathrm{~h}$. Hekla stands out for its short precursor times, 25, 23, 30, and $79 \mathrm{~min}$, repectively.

Three eruptions stand out for their unusually long precursor times, Heimaey $1973(30 \mathrm{~h})$, Gjálp $1996(34 \mathrm{~h})$, and the Bárðarbunga 2014-2015 (13 days) eruptions. The circumstances for them are quite varied. The Heimaey eruption occurred within the off-rift Vestmannaeyjar volcanic system, and the eruption apparently was fed from unusually great depth, 15$25 \mathrm{~km}$, without the involvement of a magma chamber. The premonitory activity to the Gjálp eruption all took place within the Bárðarbunga volcano and apparently involved the caldera fault, propagating dikes and subsidiary magma bodies (Einarsson et al., 1997). The eruption of Bárðarbunga 2014-2015 was a part of a major regional rifting event, and occurred at the distal end of a laterally propagating dike, at the distance of $45 \mathrm{~km}$ from the feeding magma chamber (Sigmundsson et al., 2015; Gudmundsson et al., 2016).

The precursory signals of the 21 eruptions are quite varied, but they have common characteristics that can be used to identify them in real time and issue warnings to the local population. This has been practiced in Iceland since the time of the Krafla rifting episode in the seventies. The book-keeping is shown in Table 1. A pre-eruption warning was issued in 14 of the eruptions, a success rate of $67 \%$. In four additional cases the precursory activity was detected on the instruments before the eruption was seen or verified, but after it began. In only three cases was the eruption seen before the instruments were checked.

The high detection rate is of great importance in a country where the observation conditions are not always perfect due to darkness and bad weather. It is, for example, common occurrence that a suspected eruption is reported, but subsequent checking of the monitoring networks shows no activity. The importance of such "negative warnings" should not be underestimated.

The term "false alarm" needs to be adressed. The precusory activity is generally ascribed to the propagation of a dike toward the surface. Quite frequently the dike does not reach the surface, and yet the signal is indistinguishable from that of a dike that does. The issued warning therefore has to include the possibility that the eruption may abort. Strictly speaking this is not a false alarm. A dike intrusion and its associated rifting may be just as destructive as an eruption. True false alarms have not been common in Iceland in the last 40 years. For example, the continuous inflation at Hrómundartindur in 1994-1998 and the year-long intrusion of Upptyppingar 2007-2008 never led to an alarm situation.

The short precursor times of Hekla eruptions are of particular concern. Two of the failure cases to issue warning are due to Hekla. In addition the beginning phase of the Hekla eruptions tends to be quite violent. Of the four most active Icelandic volcanoes Hekla is the only one that does not have a thick glacier cover. The rise of the eruptive column is therefore not delayed by the melting of the glacier cover and the column rises very fast. 
TABLE 1 | Short-term precursory activity and precursory times.

\begin{tabular}{|c|c|c|c|c|c|c|}
\hline & & & $\mathbf{W}$ & D & $\mathbf{V}$ & $\mathbf{T}$ \\
\hline 1966 & Surtsey & August 19 & & & $x$ & (80 min) \\
\hline 1970 & Hekla & May 5 & & & $x$ & $25 \min$ \\
\hline 1973 & Heimaey & January 23 & & & $x$ & $30 \mathrm{~h}$ \\
\hline 1975 & Krafla & December 20 & & $x$ & & $\sim 15 \min$ \\
\hline 1977 & Krafla & April 27 & $x$ & & & $(1 \mathrm{~h})$ \\
\hline 1977 & Krafla & September 8 & $x$ & & & $21 / 4 \mathrm{~h}$ \\
\hline 1980 & Krafla & March 16 & $x$ & & & $65 \min$ \\
\hline 1980 & Krafla & July 10 & $x$ & & & $5 \mathrm{~h}$ \\
\hline 1980 & Hekla & August 17 & & & $x$ & $23 \min$ \\
\hline 1980 & Krafla & October 18 & $x$ & & & $82 \min$ \\
\hline 1981 & Krafla & January 30 & $x$ & & & $7 \mathrm{~h}$ \\
\hline 1981 & Hekla & April 9 & & & $x$ & (4 h) \\
\hline 1981 & Krafla & November 18 & $x$ & & & 76 min. \\
\hline 1983 & Grímsvötn & May 28 & & $x$ & & $\sim 9 \mathrm{~h}$ \\
\hline 1984 & Krafla & September 4 & $x$ & & & $4 \mathrm{~h} 24 \mathrm{~min}$ \\
\hline 1991 & Hekla & January 17 & & $x$ & & $30 \mathrm{~min}$ \\
\hline 1996 & Gjálp & September 30 & $x$ & & & $\sim 34 \mathrm{~h}$ \\
\hline 1998 & Grímsvötn & December 28 & & $x$ & & $\sim 6 \mathrm{~h}$ \\
\hline 2000 & Hekla & February 26 & $x$ & & & $79 \min$ \\
\hline 2004 & Grímsvötn & November 1 & $x$ & & & $21 / 2-15 h$ \\
\hline 2010 & Eyjafjallajökull & Mar. 20 & & & $x$ & \\
\hline 2010 & Eyjafjallajökull & April 14 & $x$ & & & $2 \mathrm{~h} 15 \mathrm{~min}$ \\
\hline 2011 & Grímsvötn & May 21 & $x$ & & & $90 \mathrm{~min}$ \\
\hline 2014 & Bárðarbunga & August 29 & $x$ & & & 13 days \\
\hline
\end{tabular}

$\mathrm{W}$, warning issued before eruption.

$D$, detected first by instruments, then verified visually.

$V$, visual observation of eruption before instruments checked.

T, precursor time, from beginning of detected precursor until beginning of eruption.

$\sim$, means that the timing of event is imprecise.

(), means that the beginning of eruption is assumed.

This is of concern for overflying aircraft and groups of hikers on the flank of the volcano. There is heavy airtraffic over the summit of Hekla, mostly due to the unfortunate circumstance that the co-ordinate cross $64^{\circ} \mathrm{N}$ and $20^{\circ} \mathrm{W}$, a commonly used waypoint for navigation, is immediately west of the volcano.

\section{CONCLUSIONS}

1. During the time since sensitive seismograph networks were installed in Iceland, 1973-1974, at least 21 confirmed volcanic eruptions have occurred. This gives an average repose time of 2-3 years for the set of Icelandic volcanoes as a whole.

2. All confirmed eruptions during this time of observation had a detectable short-term seismic precursor.

3. The precursor times varied between $15 \mathrm{~min}$ and 13 days. In half of the cases the precursor time was $<2 \mathrm{~h}$. Three events stand out for their long precursory time, Heimaey 1973 with 30 h, Gjálp, 1996 with 34 h, and Bárðarbunga 2014-2015 with 13 days.

4. In the case of Heimaey the long precursor time is most likely the consequence of the great depth of the magma source. The Gjálp eruption had a prelude that was unusual in many respects. The long precursory time may have resulted from a complicated triggering scenario involving more than one magma chamber. The Bárðarbunga 2014-2015 eruption occurred at the distal end of a dike that took 13 days to propagate lateraly from its source until a suitable eruption site was reached.

5. Warnings to the local populations were issued prior to the beginning of 14 of the eruptions, or $67 \%$ of the cases. In 4 additional cases the precursory activity was noticed after the actual eruption began but before it was seen. The instrumental monitoring therefore gave some extra time for the benfit of the emergency response teams.

6. The few cases where no warnings were issued prior to visual verification of beginning eruptions were associated with Hekla (1980, 1981), and Eyjafjallajökull (2010 flank eruption).

7. The short precursory times for Hekla volcano are of particular concern because of rapidly increasing tourism with hiking groups on the flanks of the volcano, and the heavy airtraffic over the summit of the volcano, guided by a navigation waypoint at $64^{\circ} \mathrm{N}$ and $20^{\circ} \mathrm{W}$, slightly west of Hekla.

8. Several events occurred during the period of study, where magma movements were detected by their seismicity 
and crustal deformation signals, but did not result in eruptions. These include inflation of the Hrómundartindur volcanic system in 1994-1998, intrusions into the roots of Eyjafjallajökull in 1994, 1999, and 2009, deep intrusion at Upptyppingar in 2007-2008, and several dike intrusions in the Krafla fissure swarms in 1975-1980.

9. Several cases of suspected but unconfirmed sub-glacial eruptions exist where no eruption is seen trough the glacial cover. Eruption-like seismic signals are then detected, often in connection with jökulhlaups, i.e., glacial outburst floods from volcanic areas. These include events at Katla volcano in 1999 and 2011, Grímsvötn in 1984, Hamarinn 2011, and several events at the Skaftá Cauldrons west of Grímsvötn.

\section{AUTHOR CONTRIBUTIONS}

The author confirms being the sole contributor of this work and approved it for publication.

\section{REFERENCES}

Alfaro, R. (2001). Seismic Studies of Active Volcanoes Under Vatnajökull Icecap, Iceland. Ph.D. thesis, University of Cambridge.

Bjarnason, I. (2008). An Iceland hotspot saga. Jökull 58, 3-16.

Björnsson, A., Sæmundsson, K., Einarsson, P., Tryggvason, E., and Grönvold, K. (1977). Current rifting episode in north Iceland, Nature 266, 318-323.

Björnsson, A., and Sigurðsson, O. (1978). Hraungos úr borholu í Bjarnarflagi (Lava eruption through a borehole in Bjarnarflag, in Icelandic). Náttúrufræðingurinn $48,19-23$.

Björnsson, H., and Einarsson, P. (1990). Volcanoes beneath Vatnajökull, Iceland: Evidence from radio-echo sounding, earthquakes and jökulhlaups. Jökull 40, 147-168.

Björnsson, S., and Einarsson, P. (1974). "Seismicity of Iceland," in Geodynamics of Iceland and the North Atlantic Area, ed L. Kristjánsson (Holland: Reidel Publ. Co. Dordrecht), 225-239.

Brandsdóttir, B., and Einarsson, P. (1979). Seismic activity associated with the September 1977 deflation of the Krafla central volcano in NE-Iceland. J. Volc. Geothermal Res. 6, 197-212. doi: 10.1016/0377-0273(79)90001-5

Brandsdóttir, B., and Einarsson, P. (1992). "Volcanic tremor and low-frequency earthquakes in Iceland," in Volcanic Seismology, eds P. Gasparini and K. Aki (Berlin; Heidelberg: Springer Verlag), 212-222.

Brandsdóttir, B., and Menke, W. H. (2008). The seismic structure of Iceland. Jökull 58, 17-34.

Buck, W. R., Einarsson, P., and Brandsdóttir, B. (2006). Tectonic stress and magma chamber size as controls on dike propagation: constraints from the 1975-1984 Krafla rifting episode. J. Geophys. Res. 111:B12404. doi: 10.1029/2005JB003879

Clifton, A. E., Sigmundsson, F., Feigl, K. L., Guðmundsson, G., and Árnadóttir, T. H. (2002). Surface effects of faulting and deformation resulting from magma accumulation at the Hengill triple junction, SW Iceland, 1994-1998. J. Volcanol. Geothermal Res. 115, 233-255. doi: 10.1016/S0377-0273(01)0 0319-5

Dahm, T., and Brandsdóttir, B. (1997). Moment tensors of microearthquakes from the Eyjafjallajökull volcano in South Iceland. Geophys. J. Int. 130, 183-192. doi: 10.1111/j.1365-246X.1997.tb00997.x

Einarsson, P. (1974). Seismic Activity Recorded in Surtsey During the Summer of 1966. Surtsey Research Progress Report. Surtsey Research Society. (Reykjavík).

Einarsson, P. (1991a). Earthquakes and present-day tectonism in Iceland. Tectonophysics 189, 261-279.

Einarsson, P. (1991b). "Umbrotin við Kröflu 1975-1989 (The activity of Krafla 1975-1989, in Icelandic," in Náttúra Mývatns ed Árni Einarsson og Arnpór Garðarsson (Reykjavík: Hið Íslenska Náttúrufræðifélag), 97-139.

\section{FUNDING}

This study is the result of more than four decades of work on the seismicity of volcanoes and monitoring their activity. Funding for different aspects of the work has come from various sources, mostly the Icelandic government budget through the Science Institute, University of Iceland.

\section{ACKNOWLEDGMENTS}

This paper is a compilation of the work of many individuals involved with the monitoring of the Icelandic volcanoes and operation of the seismograph networks. The seismograms of Figures 3-5 are from the stations at Reynihlíð, Skinnastaður, and Akureyri, stations attendants were Ármann Pétursson, Sigurvin Elíasson, and Gísli Ólafsson, respectively. Ásta Rut Hjartardóttir made Figure 1. The paper benefitted from the constructive comments by two reviewers and the editors.

Einarsson, P. (2000). “Atburðarás í tengslum við hlaup í Jökulsá á Sólheimasandi í júlí 1999 (Course of events associated with jökulhlaup in Jökulsá á Sólheimasandi in July 1999, abstract in Icelandic)," in Geoscience Society of Iceland, Special Conference (Reykjavík: Geoscience Society of Iceland), 14.

Einarsson, P. (2008). Plate boundaries, rifts and transforms in Iceland. Jökull 58, $35-58$.

Einarsson, P., and Björnsson, S. (1976). Seismic activity associated with the 1970 eruption of Volcano Hekla in Iceland. Jökull 26, 8-19.

Einarsson, P., and Björnsson, S. (1987). "Jarðskjálftamælingar á Raunvísindastofnun Háskólans (Seismic studies at the Science Institute, University of Iceland, in Icelandic)," in "İ hlutarins eðli," Festschrift for Porbjörn Sigurgeirsson, ed P. Sigfússon (Reykjavík: Menningarsjóður), 251-278.

Einarsson, P., and Brandsdóttir, B. (1980). Seismological evidence for lateral magma intrusion during the July 1978 deflation of the Krafla volcano in NE-Iceland. J. Geophys. 47, 160-165.

Einarsson, P., and Brandsdóttir, B. (1984). Seismic activity preceding and during the 1983 volcanic eruption in Grímsvötn, Iceland. Jökull 34, 13-23.

Einarsson, P., and Brandsdóttir, B. (1997). Jarðfræðilegur rammi og aðdragandi eldsumbrota undir Vatnajökli 1996 (Geological framework and prelude to the volcanic activity under Vatnajökull in 1996, in Icelandic)," in Vatnajökull. Gos og hlaup 1996, ed H. Haraldsson (Reykjavík), 9-17.

Einarsson, P., Brandsdóttir, B., Guðmundsson, M. T., Björnsson, H., Grönvold, K., and Sigmundsson, F. (1997). Center of the Iceland Hotspot experiences volcanic unrest. Eos 2, 369-375. doi: 10.1029/97EO00237

Einarsson, P., and Sæmundsson, K. (1987). "Earthquake epicenters 1982-1985 and volcanic systems in Iceland (map)," in "I hlutarins eðli," Festschrift for Porbjörn Sigurgeirsson, ed P. Sigfússon (Reykjavík: Menningarsjóður).

Feigl, K., Gasperi, J., Sigmundsson, F., and Rigo, A. (2000). Crustal deformation near Hengill volcano, Iceland 1993-1998: coupling between magmatic activity and faulting inferred from elastic modelling of satellite radar interferograms. J. Geophys. Res. 105, 25655-25670. doi: 10.1029/2000JB9 00209

Finnsson, H. (1767). Efterretning om Tildragelserne ved bierget Hekla udi Island $i$ April og fölgende Maaneder 1766. Kiöbenhavn, 1767 (Report on the Events at Mt. Hekla in Iceland in April 1766 and Following Months. In Danish). Referenced in Thorarinsson, 1967b.

Geirsson, H., LaFemina, P., Árnadóttir, T., Sturkell, E., Sigmundsson, F., Travis, M., et al. (2012). Volcano deformation at active plate boundaries: Deep magma accumulation at Hekla volcano and plate boundary deformation in south Iceland. J. Geophys. Res. 117:B11409. doi: 10.1029/2012JB009400

Grönvold, K., Larsen, G., Einarsson, P., Thorarinsson, S., and Sæmundsson, K. (1983). The Hekla eruption 1980-81. Bull. Volcanol. 46, 349-363. 
Gudmundsson, Á., Óskarsson, N., Grönvold, K., Sæmundsson, K., Sigurðsson, O., Stefánsson, R., et al. (1992). The 1991 eruption of Hekla, Iceland. Bull. Volcanol. $54,238-246$

Guðmundsson, M. T., Björnsson, H., and Pálsson, F. (1995). Changes in jökulhlaup sizes in Grímsvötn, Vatnajökull, Iceland, 1934-1991, deduced from in situ measurements of subglacial lake volume. J. Glaciol. 41, 263-272.

Gudmundsson, M. T., Högnadóttir, T., Björnsson, H., and Pálsson, F. (2000). "Jarðhitinn í Mýrdalsjökli og atburðirnir sumarið 1999 (Geothermal activity beneath Mýrdalsjökull and the events of the summer of 1999, abstract in Icelandic)," in Geoscience Society of Iceland, Special Conference (Reykjavík: Geoscience Society of Iceland), 13.

Gudmundsson, M. T., Jónsdóttir, K., Hooper, A., Holohan, E. P., Halldórsson, S. A., Ófeigsson, B. G. et al. (2016). Gradual caldera collapse at Bárdarbunga volcano, Iceland, regulated by lateral magma outflow. Science 353:aaf8988. doi: $10.1126 /$ science.aaf8988.

Guðmundsson, M. T., Pedersen, R., Vogfjörd, K., Thorbjarnardóttir, B., Jakobsdóttir, S. S., and Roberts, M. J. (2010). Eruptions of Eyjafjallajökull Volcano, Iceland. Eos 91, 190-191. doi: 10.1029/2010EO210002

Guðmundsson, M. T., and Björnsson, H.(1991). Eruptions in Grímsvötn 19341991. Jökull 41, 21-46.

Guðmundsson, M. T., Sigmundsson, F., and Björnsson, H. (1997). Ice-volcano interaction of the 1996 Gjálp subglacial eruption, Vatnajökull, Iceland. Nature $389,954-957$.

Gudmundsson, M. T., Sigmundsson, F., Björnsson, H., and Högnadóttir, T. (2004). The 1996 eruption at Gjálp, Vatnajökull ice cap, Iceland: Course of events, efficiency of heat transfer, ice deformation and subglacial water pressure. Bull. Volc. 66, 46-65. doi: 10.1007/s00445-003-0295-9

Gudmundsson, M. T., Thordarson, T., Höskuldsson, Á., Larsen, G., Björnsson, H., Prata, F. J., et al. (2012). Ash generation and distribution from the April-May 2010 eruption of Eyjafjallajökull, Iceland. Sci. Rep. Sci. Rep. 2:572. doi: $10.1038 /$ srep00572

Heimisson, E. R., Einarsson, P., Sigmundsson, F., and Brandsdóttir, B. (2015). Kilometer- scale Kaiser effect identified in Krafla volcano, Iceland. Geophys. Res Lett. 42, 7958-7965. doi: 10.1002/2015GL0 65680

Hjaltadóttir, S., Vogfjörd, K. S., Hreinsdóttir, S., and Slunga, R. (2015). Reawakening of a volcano: activity beneath Eyjafjallajökull volcano from 1991 to 2009. J. Volc. Geotherm. Res. 304, 194-205 doi: 10.1016/j.jvolgeores.2015.08.001

Hjartardóttir, Á. R., Einarsson, P., Guðmundsson, M. T., and Högnadóttir, Th. (2016). Fracture movements and graben subsidence during the 2014 Bárðarbunga dike intrusion in Iceland. J. Volc. Geother. Res. 310, 242-252. doi: 10.1016/j.jvolgeores.2015.12.002

Hooper, A., Ofeigsson, B. G., Sigmundsson, F., Lund, B., Geirsson, H., Einarsson, P., et al. (2011). Increased capture of magma in the crust promoted by ice-cap retreat in Iceland. Nat. Geosci. 4, 783-786. doi: 10.1038/ngeo1269

Hreinsdóttir, S., Sigmundsson, F., Árnadóttir, T. H., Gudmundsson, M. T., Oddsson, B., Ofeigsson, B. G., et al. (2014). Volcanic plume height correlated with magma-pressure change at Grímsvötn Volcano, Iceland. Nat. Geosci. 7, 214-218. doi: 10.1038/ngeo2044

Jakobsdóttir, S. S., Roberts, M. J., Guðmundsson, G. B., Geirsson, H., and Slunga, R. (2008). Earthquake swarms at Upptyppingar, North-East Iceland: a sign of magma intrusion? Stud. Geophys. Geod. 52, 513-528. doi: $10.1007 / \mathrm{s} 11200-008-0035-\mathrm{x}$

Jakobsson, S. (1979a). Outline of the petrology of Iceland. Jökull 29, 57-73.

Jakobsson, S. (1979b). Petrology of recent basalts of the eastern volcanic zone, Iceland. Acta Nat. Isl. 26, 103.

Jakobsson, S., Jónasson, K., and Sigurðsson, I. A. (2008). The three igneous rock series of Iceland. Jökull 58, 117-138.

Linde, A. T., Ágústsson, K., Sacks, I. S., and Stefánsson, R. (1993). Mechanism of the 1991 eruption of Hekla from continuous borehoe strain monitoring. Nature 365, 737-740. doi: 10.1038/365737a0

Ofeigsson, B. G., Hooper, A., Sigmundsson, F., Sturkell, E., and Grapenthin, R. (2011). Deep magma storage at Hekla volcano, Iceland, revealed by InSAR time series analysis. J. Geophys. Res. 116:B05401. doi: 10.1029/2010JB007576

Pedersen, R., and Sigmundsson, F. (2004). InSAR based sill model links spatially offset areas of deformation and seismicity for the 1994 unrest episode at Eyjafjallajökull volcano, Iceland. Geophys. Res. Lett. 31:L14610. doi: 10.1029/2004GL020368

Pedersen, R., and Sigmundsson, F. (2006). Temporal development of the 1999 intrusive episode in the Eyjafjallajökull volcano, Iceland, derived from InSAR images. Bull. Volcanol. 68, 377-393. doi: 10.1007/s00445-005-0020-y

Pedersen, R., Sigmundsson, F., and Einarsson, P. (2007). Controlling factors on earthquake swarms associated with magmatic intrusions; constraints from Iceland. J. Volcanol. Geothermal Res. 162, 73-80. doi: 10.1016/j.jvolgeores.2006.12.010

Rögnvaldsson, S., Árnadóttir, T., Ágústsson, K., Skaftadóttir, T., Guðmundsson, G. B., Björnsson, G., et al. (1998). Skjálftahrina i Ölfusi í Nóvember 1998. Icelandic Meteorological Office, Report VÎ-G98046-JA09, 19.

Sæmundsson, K. (1974). Evolution of axial rifting zone in northern Iceland and the Tjörnes Fracture Zone. Geol. Soc. Am. Bull. 85, 495-504. doi: 10.1130/00167606(1974) $85<495$ :EOTARZ $>2.0 . C O ; 2$

Sæmundsson, K. (1978). Fissure swarms and central volcanoes of the neovolcanic zones of Iceland. Geol. J. 19, 415-432.

Sæmundsson, K. (1991). "Jarðfræði Kröflukerfisins (Geology of the Krafla volcanic system, in Icelandic)," in Náttúra Mývatns, ed Á. Einarsson and A. Garðarsson (Reykjavík: Hið Íslenska Náttúrufræðifélag), 25-95.

Sgattoni, G., Guðmundsson, Ó., Einarsson, P., Lucchi, F., Li, K. L., Sadeghisorkhan, H., et al. (2017). The 2011 unrest at Katla volcano: location and interpretation of the tremor source. J. Volcanol. Geother. Res. 338, 63-78. doi: 10.1016/j.jvolgeores.2017.03.028

Sgattoni, G., Jeddi, Z., Guðmundsson, Ó., Einarsson, P., Tryggvason, A., Lund, B., et al. (2016). Long-period events with striking regular time pattern on Katla volcano's south flank (Iceland). J. Volcanol. Geothermal Res. 324, 28-40. doi: 10.1016/j.jvolgeores.2016.05.017

Sigmarsson, O., MacLennan, J., and Carpentier, M. (2008). Geochemistry of igneous rocks in Iceland: a review, 2008. Jökull 58, 139-160.

Sigmundsson, F., Einarsson, P., Rögnvaldsson, S., Foulger, G. R., Hodgkinson, K. M., and Thorbergsson, G. (1997). The 1994-1995 seismicity and deformation at the Hengill triple junction, Iceland: triggering of earthquakes by minor magma injection in a zone of horizontal shear stress. J. Geophys. Res. 102, 151-161.

Sigmundsson, F., Hooper, A., Hreinsdóttir, S., Vogfjörd, K., Ofeigsson, B. G., Heimisson, E. R., et al. (2015). Segmented lateral dyke growth in a rifting event at Bárðarbunga volcanic system, Iceland. Nature 517, 191-195. doi: $10.1038 /$ nature14111

Sigmundsson, F., Hreinsdóttir, S., Hooper, A., Árnadóttir, T., Pedersen, R., Roberts, M. J., et al. (2010). Intrusion triggering of the 2010 Eyjafjallajökull explosive eruption. Nature 468, 426-430. doi: 10.1038/nature09558

Soosalu, H., and Einarsson, P. (2002). Earthquake activity related to the 1991 eruption of the Hekla volcano, Iceland. Bull. Volc. 63, 536-544. doi: 10.1007/s00445-001-0177-y

Soosalu, H., and Einarsson, P. (2004). Seismic constraints on magma chambers at Hekla and Torfajökull volcanoes, Iceland. Bull. Volcanol. 66, 276-286. doi: 10.1007/s00445-003-0310-1

Soosalu, H., and Einarsson, P. (2005). Seismic characteristics of the Hekla volcano and its surroundings, Iceland. Jökull 55, 87-106.

Soosalu, H., Einarsson, P., and Jakobsdóttir, S. (2003). Volcanic tremor related to the 1991 eruption of the Hekla volcano, Iceland. Bull. Volcanol. 65, 562-577. doi: 10.1007/s00445-003-0285-y

Soosalu, H., Einarsson, P., and Thorbjarnardóttir, B. (2005). Seismic activity associated with the 2000 eruption of Hekla, Iceland. Bull. Volcanol. 68, 21-36. doi: 10.1007/s00445-005-0417-7

Soosalu, H., Lippitsch, R., and Einarsson, P. (2006). Low-frequency earthquakes at the Torfajökull volcano, south Iceland. J. Volcanol. Geothermal Res. 153, 187-199. doi: 10.1016/j.jvolgeores.2005.10.012

Stefánsson, R., Böðvarsson, R., Slunga, R., Einarsson, P., Jakobsdóttir, S., Bungum, H., et al. (1993). Earthquake prediction research in the South Iceland seismic zone and the SIL project. Bull. Seismol. Soc. Am. 83, 696-716.

Sturkell, E., Einarsson, P., Sigmundsson, F., Geirsson, H., Pedersen, R., Van Dalfsen, E., et al. (2006). Volcano geodesy and magma dynamics in Iceland. J. Volcanol. Geothermal Res. 150, 14-34. doi: 10.1016/j.jvolgeores.2005. 07.010

Sturkell, E., Einarsson, P., Sigmundsson, F., Hreinsdóttir, S., and Geirsson, H. (2003a). Deformation of Grímsvötn volcano, Iceland: 1998 
eruption and subsequent inflation. Geophys. Res. Lett. 30, 1182-1185. doi: 10.1029/2002GL016460

Sturkell, E., Ágústsson, K., Linde, A. T., Sacks, S. I., Einarsson, P., Sigmundsson, F., et al. (2013). New insights into volcanic activity from strain and other deformation data for the Hekla 2000 eruption. J. Volcanol. Geother. Res. 256, 78-86. doi: 10.1016/j.jvolgeores.2013. 02.001

Sturkell, E., Sigmundsson, F., and Einarsson, P. (2003b). Recent unrest of the Eyjafjallajökull and Katla volcanoes, Iceland. J. Geophys. Res. 108, 2369-2381. doi: 10.1029/2001JB00091

Thorarinsson, S. (1964). Surtsey. Eyjan nýja á Atlantshafi. (Surtsey. The New Island in the North Atlantic, in Icelandic). Reykjavík: Almenna Bókafélagið.

Thorarinsson, S. (1965). Neðansjávargos við Ísland (Submarine eruptions off Iceland, in Icelandic). Náttúrufreeðingurinn 35, 49-74.

Thorarinsson, S. (1966). Sitt af hverju um Surtseyjargosið (Bits and pieces on the Surtsey eruption, in Icelandic). Náttúrufreðingurinn 35, 153-181.

Thorarinsson, S. (1967a). The Surtsey eruption and related scientific work. Polar Record. 13, 571-578. doi: 10.1017/S0032247400058113

Thorarinsson, S. (1967b). The eruption of Hekla 1947-1948: I. The Eruptions of Heklain Historical Times, a Tephrochronological Study. Reykjavík: Soc Scientiarum Islandica.

Thorarinsson, S. (1968). Síðustu pættir Eyjaelda (The last phases of the Surtsey eruption, in Icelandic). Náttúrufreðingurinn 38, 113-135.

Thorarinsson, S. (1970). Hekla, a Notorious Volcano. Reykjavík: Almenna Bókafélagið.

Thorarinsson, S. (1975). Katla og annáll Kötlugosa (Katla and Annal of its Eruptions, in Icelandic). Reykjavík: Árbók Ferðafélags Íslands.

Thorarinsson, S., Einarsson, T. H., Sigvaldason, G. E., and Eliasson, G. (1964). The submarine eruption off the Vestmann Islands 1963-64, a preliminary report. Bull. Volcanol. Tome XXVII, 1-11.

Thorarinsson, S., and Sigvaldason, G. E. (1972). The Hekla eruption of 1970. Bull. Volcanol. 36, 269-288. doi: 10.1007/BF02596870

Thorarinsson, S., Steinthorsson, S., Einarsson, T., Kristmannsdottir, H., and Óskarsson, N. (1973). The eruption on Heimaey, Iceland. Nature 241, 372-375. doi: $10.1038 / 241372 \mathrm{a} 0$
Thoroddsen, T. H., (1925). Die Geschichte der isländischen Vulkane (The History of Icelandic Volcanoes, in German). The Royal Danish Science Society, Division of Natural Sciences and Mathematics, Series 8, (Copenhagen).

Tryggvason, E. (1960). Earthquakes, jökulhlaups and subglacial eruptions. Jökull $10,18-22$.

Tryggvason, E. (1984). Widening of the Krafla fissure swarm during the 1975-1981 volcano-tectonic episode. Bull. Volcanol. 47, 47-69. doi: 10.1007/BF01960540

Vogfjörd, K. S., Jakobsdóttir, S. S., Gudmundsson, G. B., Roberts, M. J., Ágústsson, K., Arason, T., et al. (2005). Forecasting and monitoring of a volcanic eruption in Iceland. Eos 86, 245-248. doi: 10.1029/2005EO260001

Walker, G. P. L. (1993). "Basaltic volcano systems," in Magmatic Processes and Plate Tectonics, eds H. M. Pritchard, T. Alabaster, B. W. Harris, and C. Neary (London: Geological Society, Special Publications No. 76), 3-38.

Ward, P. L., and Björnsson, S. (1971). Microearthquakes, swarms and and the geothermal areas of Iceland. J. Geophys. Res. 76, 3953-3982. doi: 10.1029/JB076i017p03953

Ward, P. L., Pálmason, G., and Drake, C. L. (1969). Microearthquakes surveys and the mid-Atlantic ridge in Iceland. J. Geophys. Res. 74, 665-684. doi: 10.1029/JB074i002p00665

White, R. S., Drew, J., Martens, H. R., Key, J., Soosalu, H., and Jakobsdóttir, S. S. (2011). Dynamics of dyke intrusion in the mid-crust of Iceland. Earth Planet. Sci. Lett. 304, 300-312. doi: 10.1016/j.epsl.2011.02.038

Wright, T. J., Sigmundsson, F., Ayele, A., Belachew, M., Brandsdottir, B., Calais, E., et al. (2012). Geophysical constraints on the dynamics of spreading centres from rifting episodes on land. Nat. Geosci. 5, 242-250. doi: 10.1038/ngeo1428

Conflict of Interest Statement: The author declares that the research was conducted in the absence of any commercial or financial relationships that could be construed as a potential conflict of interest.

Copyright $\odot 2018$ Einarsson. This is an open-access article distributed under the terms of the Creative Commons Attribution License (CC BY). The use, distribution or reproduction in other forums is permitted, provided the original author(s) and the copyright owner are credited and that the original publication in this journal is cited in accordance with accepted academic practice. No use, distribution or reproduction is permitted which does not comply with these terms. 